\title{
THE FUTURE OF EDUCATION FOR THE INFORMATION PROFESSIONS
}

\author{
by Adele Fasick
}

\begin{abstract}
Although technology and the Internet have enabled the information professions to make huge strides, there are still many issues to be resolved. This article outlines and discusses many of them including environmental changes; linking - access, knowledge of location is not enough to access information; the proposed Information Commons by the University of Toronto; changes in definition of professions; the need for alternative delivery of education and for service orientation. Finally, the need for flexible basic education for Information Studies students is emphasized in order to guarantee the future of the profession.
\end{abstract}

The information professions are undergoing dynamic change. Almost every month brings a new advance in information handling. The growth of the Internet has made it possible for individuals to access information from a computer terminal rather than making a trip to a library. Information professionals educated ten, five, or even one year ago are having to learn new skills and new ways of interacting with their clients. For educators, the challenge is to prepare students for a lifelong career at a time when no one knows for certain what shape the future delivery of information will take. The library of the past was a fairly stable institution evolving over time, but not dramatically changing its mission or its methods. Now information is being delivered in different settings and using different technologies. Education for professionals is designed to prepare them for the working conditions they will face, so educators are taking a hard look at various predictions about the future of libraries and other information agencies.

What will the information centre of the future look like? Many writers proclaim the birth of a digital world where all information can be accessed from home by individuals equipped with a computer and a modem. Other knowledgeable writers agree with Clifford Stoll who writes, "I claim that this bookless library is a dream, a hallucination of online addicts, network neophytes, and library-automation insiders" (Stoll, 1995, p. 176) How can the profession chart a course for the future in such a chaotic environment? One way to make a start is to look at where we have come from in the last ten years and what the major systemic changes have been in our profession.

\section{CHANGES AFFECTING THE INFORMATION PROFESSIONS}

\section{Technological Changes}

Technology has been the most important factor in changing the information professions. The change has come in three major waves: access points; electronic storage of text and graphics; and new delivery systems.

The provision of new access points was the first major effect of technology. The computer made it possible to put huge library catalogues on microfilm, online, and on CD-ROMs. This has enabled people to search for information in catalogues in ways that were impossible before. It is true, as Nicholson Baker (1994) wrote in the New Yorker, that some information has been lost in the transfer to electronic catalogues. But both professionals and users love the new catalogues because they make searching faster and easier. They also increase the demand for materials by making potential users aware of sources they may not have heard of before.

The next step after making local catalogues available online was to link catalogues across the country and, to some extent, around the world. For professionals and for users who can search it on their own, this reveals a wealth of material that could be of value to the researcher. The problem is access. It is all very well to know that the Harvard University or the British Library holds the very title a student wants, but if the deadlines are tight, as they so often are, the material is likely to go unused. Knowledge about location is one thing, but it is not equivalent to making the material accessible. Michael Buckland (1992) discusses the changes made by libraries as they moved from being 
what he calls paper libraries to automated libraries. The most recent development, as Buckland points out, is the move to the electronic library, now more frequently called the digital library.

The digital library moves beyond the electronic storage of information about the location of materials into the electronic storage of text and graphics themselves. Few people want to know that information is available in a collection two thousand miles away. What they want is to be able to access the information on their computer, download it, print it out, and have a text of their own to study. This is the vision the media is selling to people and this is often what they expect. Reality, of course, falls far short. Full-text databases are a small part of all the information available, and quite often they are difficult to access or are restricted. The Internet is a vast resource of information but much of it is almost impossible to locate and to evaluate for its validity. The profusion of data on the Internet and the lack of a coherent scheme of organizing and accessing it offers a great opportunity to information professionals.

\section{Environmental Changes}

Information technology has been the driving force behind many of the changes in the profession, but it is not so much the technology itself but rather the social changes that it brings that will have the major impact. Much has been written about the electronic or digital library and the ways in which information will be made available, but the problem of how this affects information jobs is less frequently addressed. Malinconico (1992) writes, "We have done an admirable job envisioning the information technologies of the future and preparing people to use them, but we have not done as good a job projecting how these developments might alter management and organizational structures associated with information resources..."

Increasingly the library, whether academic or corporate, will become a part of an overall, integrated information system. People will expect to access both published materials and the raw data from laboratories and business operations. The development of Information Commons or other such access points to information within an academic community may be copied by corporations and communities. The purpose and scope of an Information Commons is described in a planning document of the University of Toronto:

We propose that the Information Commons have a front help desk serving as a single point of contact for information technology support, supported by specialized support "desks" and electronic and printed resource guides....The front help desk should be accessible by telephone, e-mail, and the World Wide Web....We envision the Information Commons as a highly visible and easily accessed place staffed by librarians, research assistants, and technology experts, where students, faculty, researchers, and staff can come to find out about information technology, to learn how to make use of it, and to actually use and develop appropriate tools to retrieve and manipulate information. (Biderman, 1994)
Working in an Information Commons environment requires professionals who understand the range of information technology and the ways in which people use it, and who can work with individuals and groups to make the cooperative project operate efficiently.

The availability of electronic information makes new delivery systems directly to home and office imperative. The digital library is not yet a reality except in trial runs, but it is clearly the direction in which we are moving. There is no building adequate to house all of the information available on the Internet, no library that could possibly subscribe to every journal that any one of its clients might want to use, and no institution that could keep up with all of the information that becomes available in any one day. People who depend on information for their jobs or who have a keen interest in it for their leisure activities, will expect to have what they want available when they want it in their homes or of fices. Where does this leave the information professional? Many jobs will consist of sorting through the deluge of data and preparing manageable chunks for individuals or groups. Value added services to scan the Internet and retrieve information and make it useful will fill a need.

There is evidence that people want and need knowledgeable professionals to guide their searches for information. Writing to a listserv on public library services, Schneider (1995) makes this point clearly:

I think the new media offers an opportunity for us to expand our roles and carve out space in the electronic turf. Here's an example. One weekend, as a favor, I pinch-hit a demo for a provider... I started out by describing the provider and moved on to demonstrating the World Wide Web. I happened to mention that I was a librarian... all of a sudden the crowd changed. They began peppering me with questions. They didn't want me to peddle services; they wanted me to be a librarian-someone they could trust who would guide them.....what they don't want is for me to pretend that I believe all data is equal. They want us to continue the dangerous and important work of passing judgment and sharing our informed decisions.

\section{Changes in Definition of Professions}

Technology is also a component of another development which is affecting education for information professionals. That is convergence. Several groups of people who once thought of themselves as separate and distinct professions, are drawing together. These groups include librarians, information scientists and archivists, as well as records managers, information systems managers, and the vague category of researchers. Twenty or thirty years ago many library schools were segregated into the traditional librarians who dealt with catalog cards and the reference interview, and information scientists who sat down in the basement fiddling around with punched cards and feeding them into the computer. Archivists were convinced that their methods of dealing with scholars had nothing in common with 
libraries, and records managers were glorified clerks with large filing cabinets. Now all of that is changing. Professionals who work with information recognize that there are strong similarities in their work and that they share many of the same educational needs. A UNESCO pamphlet summed up the advantages of the harmonization of education as permitting better use of facilities; better use of administrative resources; broadening the outlook of students and facilitating professional mobility; and strengthening the representative nature of professional organizations in their dealings with third parties, e.g. public authorities (nationally and locally), education circles, users (UNESCO, 1984).

The nature of information work has changed. The growth of demand for archivists and for information systems professionals as well as the changing demands of work in libraries have driven the restructuring of library school curricula. During the next five years many "library schools" will become more broadly recognized as a leader not only in library education but also in the education of archivists and information systems people. Faculty will work more closely with a number of other departments because of the interdisciplinary nature of much of the work.

The explosion of information and the obvious advantages to users of being able to access libraries, archives and other records in similar ways led to conversations and eventual cooperation among these professions. It is more than the machine that serves as a link between information professionals. It is the recognition by the public and by government that information is one of the most valuable of national resources. Issues of privacy, free access, copyright, and the health of Canada's publishing and media industries have raised questions for everyone dealing with information.

Graduates of Information Studies programs will have to think more broadly about how their jobs will evolve. They might be hired as a special librarian but find themselves managers of information systems for the corporation. Even if the job title remains unchanged, the librarian may be made responsible for supervision of the archives or of records management. Titles and job descriptions have not kept up with the changing needs of corporations and institutions. Information professionals may be given, or may take, the opportunity to develop a crucial role in the parent organization as the person who knows how to store, organize, and use information effectively.

\section{EDUCATION FOR A CHANGING PROFESSION}

\section{Need for Flexible Basic Education}

Historically, library schools concentrated on preparing students to work in libraries because libraries were the principal agencies for storing information and making it accessible. Now these schools must move to a different vision and recognize themselves as schools dealing with information rather than with an institution, whether it is called a library or an information agency or anything else. Instead of defining the type of information that needs to be collected and accessed, the schools will be educating professionals to address the many ways in which information can be generated, stored and accessed. The focus of information access has moved from an institution or storage point holding information to the individual who can pluck information from whatever environment in which it is found.

Because the format of information and the method of its delivery is changing so quickly, it is no longer useful for universities to teach students how to work in a particular environment or with specific sources. Information education is less likely to follow practice and more likely to lead it by becoming based more firmly on theory and research. Students in Information Studies programs must leam the basic principles of what information is so that they will be ready to handle it in whatever form it appears, not only at the present time but in the changing formats of the twenty-first century. This means that students need an understanding of the theories and research relating to information use and users.

Graduates of today know that the specifics they leam in their courses will be obsolete by the time they have been on the job for a year or two. As one employer of librarians wrote,

I expect new information professionals to be technology savvy - not in how to use today's hot application, but in the base level of technology - how protocols work, how the network fits together, who's doing exciting things in various topic areas. Very few schools are teaching these skills, and it's a rare student who emerges with the skills that makes me want to hire them. (Sreebny, 1995)

Unless the schools can develop curricula that will enable students to understand the basic theories and keep up with technological and other developments, their programs will become obsolete.

Employers will come to realize that the graduates of the new programs will not be trained to work in specific environments. This will mean that institutions will have to take on a greater responsibility for on-the-job training to teach new employees how information is handled in a particular location. In exchange for the loss of immediate readiness for job performance, the employer will gain an employee who can see beyond the details of daily performance and move quickly into planning and managing information use in the institution.

\section{Need for Service Orientation}

Another key to the future of education for information professionals is service. Value-added service is a vital component of what professionals offer to information-rich consumers. Students must leam that they will be working with individuals as guides through the abundance of information in their environment. Libraries will no longer be the only source of information, instead they will become routing stations which identify and locate the information needed. Someone is going to offer information services and if librarians do not do it, there will be a new profession growing up that will. 
The other kind of service which information professionals must provide is service to marginalized groups. While many corporations are happily moving into the multi-media computer and networked environment, there are still many people whose information is limited to what they see on television or listen to on the radio. These may be young people growing up in isolated rural regions or in inner cities; middle-aged people who have lost the traditional jobs they held and don't know where to turn; people with limited print literacy--there are many categories of the information deprived. Information Studies programs have a responsibility to educate students as leaders in developing information policy. Unless information professionals become a strong voice for universal access to information for all members of society, the gulf between the information-rich and the information-poor will grow. The public library has for almost a hundred years been a means of diminishing the intellectual gulf between the rich and the poor. As the public library changes its function, information professionals must keep in mind the importance of providing universal access, of insuring that govemment regulation prevents all information from becoming a commodity to be sold to the highest bidder.

\section{Need for Alternative Delivery of Education}

Education for information professionals has been affected by demographic changes as has all post-secondary education. Adults who have entered the workforce often find after five, ten, or fifteen years of work that their jobs have changed beyond recognition or that they have disappeared. Re-education for new jobs is becoming the norm and the number of mature adults who are entering Information Studies programs is increasing. Many of these people are unable to attend a program full time and programs will increasingly be offered on a part time basis and often in a distance education mode. As Hannigan (1993 p. 19) writes, "The growth of the new communications has particularly increased the potential for online interactive communication through computer networks." Professor Hannigan presents a synthesis of research that demonstrates the effectiveness of distance education when it is planned to take advantage of the interactivity made possible by current information technology.

Information Studies programs, because they are built upon expertise in information delivery, should be among the first professional schools to move to the flexibility of distance education. This will enable students who are not close to major universities to study at centres in their own area, or in their own home. The most likely pattern to emerge is one in which many courses are delivered in a distance mode, but provision is made for students to gather and interact with one another and with faculty members at various points in their programs.

Graduates of Information Studies programs will find that their skills need constant upgrading. The content of many courses now taught was unimaginable even five years ago. Continuing education therefore is a necessity and the educational programs that offer professional degrees are the logical institutions to provide them.
Although continuing professional education has been considered a part of librarians' commitment for many years, its shape and direction are changing. There is a growing body of literature on the importance and effectiveness of continuing professional education. Programs must be aimed at mature people. "Professionals are complex and sophisticated learners. They have systems for incorporating new information into competence and performance." (Bennett and Fox p. 268) Continuing education programs must be designed to take advantage of the leaming styles professionals bring to the courses. This will be a challenge to faculty accustomed to teaching novices about the intricacies of information handling. Effective continuing education is probably best designed as a cooperative effort between Information Studies programs and professionals in the field.

Information technology offers many options for the delivery of continuing education. Internet users "are greatly empowered by the ability to learn, read, conduct research, write , network, teach, and attend conferences from the convenience of the desktop at low individual cost and at times of their choosing." (Monty and Warren-Wenk, 1994). The possibilities opened up by the increasing interconnectivity of information professionals have only begun to be explored. The gap between faculties in information programs and practitioners in the field may finally be bridged by their ability to interact on many levels via the Internet.

\section{CONCLUSION}

Like most rewarding occupations, the information profession is one that is constantly evolving. Changes in technology have been the most visible and publicized aspect of professional change, but changes in the environment in which information is disseminated as well as changes in definition of traditional occupations have also had dramatic impact. The challenge to professional information programs is to recruit and educate students who can demonstrate that they have the talents and the expertise to adapt to these changes and to ensure that information remains a valuable and accessible resource for society.

Educators of information professionals need to reach beyond the traditional pool of applicants who come chiefly from the humanities disciplines and encourage science and social science majors to enter the field. They need to make greater efforts to attract students from a wider range of social and ethnic backgrounds than those who were drawn to library programs in the past. More effective publicity about the range and opportunity of information programs should attract many new university graduates as well as people seeking an occupational change.

There are many opportunities for educators to develop innovative programs that include the needs outlined above: a flexible basic education that will enable graduates to cope with change; the development of a service orientation that will focus on the needs of consumers of information; and, alternative delivery methods to enable individuals at a distance from universities to obtain the professional education they want. 
The opportunity for developing innovative programs that have a major impact on society comes at a time when economic resources are being squeezed. This is not a good time for a discipline to be expanding and changing, but we cannot choose our own time. Information management, in all of its forms, is the fastest growing area of the economy. Graduates of Information Studies programs have the opportunity to become leaders in this growth. All segments of the profession--educators, employers, practitioners, and students--must work together to ensure that the profession flourishes.

\section{REFERENCES}

Baker, N. (1994, April 4, 1994). Discards. The New Yorker, pp. 64-86.

Bennett, N. L., \& Fox, R. D. (1993). Challenges for Continuing Professional Education. In L. Curry, J. F. Wergin, \& Associates and (Ed.), Educating Professionals; Responding to New Expectations for Competence and Accountability (pp. 262-). San Francisco: Jossey-Bass.

Biderman, B. (1994). Proposal for a University of Toronto "Information Commons": Information Technology Made Visible and Accessible. Toronto: University of Toronto Instructional and Research Computing (n.p).

Buckland, M. (1992). Redesigning Library Services: A Manifesto.Chicago: American Library Association. 82pp

Hannigan, J. A. (1993). Distance Leaming and Interactivity. In Project Century 21: A Research and Action Program for Meeting the Information Needs of Society; Background
Papers (pp. 19-42). Chicago: American Library Association. President's Committee on Project Century 21.

Malinconico, S. M. (1992, Summer). What Librarians Need to Know to Survive in an Age of Technology. Journal of Library and Information Science Education, 33 (3), 226240.

Monty, V., \& Warren-Wenk, P. (1994, Spring). Using the INTERNET as a Professional Development Tool: An Analysis. Education Libraries 18 (1), 7-10.

Project Century 21: A Research and Action Program for Meeting the Information Needs of Society: Background Papers. (1993). Chicago: American Library Association. President's Committee on Project Century 21.

Schneider, K. G. (1995, Feb. 28). Gift URLs and Cybrarianship. Public Library Discussion Group (PUBLIBNET@NYSERNET>ORG)

Sreebny, O. (1995, March 30). Re: Cristal-ed V \#7. Library Education Discussion Group (CRISTAL_ED_DIGEST@sils.umich.edu)

Stoll, C. (1995). Silicon Snake Oil: Second Thoughts on the Information Highway. New York: Doubleday. 247 pp.

UNESCO. (1984). Harmonization of Training in Librarianship, Information Science, and Archives. Paris: UNESCO.

Adele Fasick is member of the Faculty of Information Studies at University of Toronto, Ontario, Canada. 